\title{
EFFECT OF A COMPLEMENTARY APPLICATION OF ALGIFOL NUTRIENT SOLUTION AND NPK ON GROWTH, FLOWERING AND YIELD OF TOMATO IN A NORTHERN GUINEA SAVANNA SOIL OF NIGERIA
}

B. O. UKEM

(Received 7 January, 2009; Revision Accepted 19 June, 2009)

\begin{abstract}
The effect of a complementary application of Algifol nutrient solution (Alg) and inorganic NPK fertilizers on growth, flowering and yield of tomato was investigated in 1999 and 2000 at Samaru, Kaduna State of Nigeria. Four levels of the nutrient solution were applied as $(2,1,12$ and $2 \mathrm{Alg})$ at the rates of $5,10,15$ and $20 \mathrm{ml}$ per $100 \mathrm{ml}$ of water while the NPK levels were applied as $\left(3,2\right.$, : and 1 or Full NPK) at the rate of 125:50:50kgha ${ }^{-1}, \mathrm{~N}, \mathrm{P}_{2} \mathrm{O}_{5}$ and $\mathrm{K}_{2} \mathrm{O}$ respectively. The combined Algifol and NPK levels were $2 \mathrm{Alg}+$ Full Alg, $1 \mathrm{Alg}+1 / 4 \mathrm{NPK}, 1 \mathrm{Alg}+1 / 2 \mathrm{NPK}, 1 \mathrm{Alg}+$ : NPK, $1 \mathrm{Alg}+$ Full NPK, $12 \mathrm{Alg}+2 \mathrm{NPK}$ and $2 \mathrm{Alg}+3 \mathrm{NPK}$ at the same rates for the Algifol and NPK and one control. Parameters measured were plant height, number of leaves, number of flowers, fresh fruit yield and dry fruit yield per plant. The results obtained showed that the fertilizer treatment effect on plant height was not significant at 6 and 12 weeks after transplant (WAT) in 1999 but in 2000, the treatment effect was highly significant $(P=0.01)$. Foliage production in 1999 and 2000 was not significant at 6WAT but highly significant at 12WAT indicating a positive influence of the treatments at the time of growth maturity relative to the initial growth period of the crop. Also, the treatment effects on flowering and dry fruit yield per plant were highly significant $(P=0.01)$ in the two years of study whereas in the fresh fruit yield, the effect was significant $(P=0.05)$ in 1999 and highly significant in the second trial in 2000. Number of flowers per plant was positively and highly significantly correlated $\left(r=0.75^{* *} ; 0.86^{* *}\right)$ with fresh fruits and dry fruits yields respectively. Treatments having both Algifol nutrient solution and inorganic NPK combinations recorded the best flowering and fruit yield in relation to the single doses of Algifol or NPK.
\end{abstract}

KEYWORDS: Nutrient solution, savanna soil, combined application, Alfisol

\section{INTRODUCTION}

The fertility status of the Nigerian savanna soils has been investigated by a number of researchers. These researchers reported that the savanna soils of Nigeria are generally coarse textured, deficient in major plant nutrients mainly $\mathrm{N}$ and phosphorus. The soils are inherently low in organic matter content and have low activity clays (Jones and Wild, 1975; Nnadi and Balasubramanian, 1980; Lombin, 1987; Uyovbisere and Lombin, 1991 and Chude et al., 2001).

Consequently, yield per hectare of most staple crops have consistently been low (Fed. Office of Statistics, 2004). A good response is often obtained leading to improvements in crop yield when these nutrients are supplied through inorganic fertilizer application and effective management practices sustained. However, the negative impacts on the environment such as increased soil acidity, weakening of soil structure, a reduction in microbial and faunal populations and ground water pollution caused by continual use of chemical fertilizers without any sustainable organic inputs needs to be addressed.

Agricultural crop production in many locations of the world currently suggests the adoption of an integrated organic and inorganic inputs especially use of readily decomposable biological material; which presents a balanced nutritional requirements of crops leading to improved crop yield and quality and at the same time improving soil physical conditions (Hulugalle et al., 1987) and sustaining soil nutrients for the succeeding crop (FAO, 1989; Singh et al., 1995; Tarfa et al., 2001). It is for the above reasons that a coapplication of solid NPK and foliarly applied organic based Algifol nutrient solution was tested on tomato in the Northern Guinea savanna agro-ecological zone of Nigeria.

Complementary use of foliar and soil applied nutrients is beneficial in terms of crop growth and yield (Abubakar, 1999). It also promotes early crop maturity and a reduction in the rates of inorganic nitrogen fertilization which in turn leads to a decline in soil and ground water pollution. In addition to these, foliar fertilization enhances micronutrients availability and use by crops. Effiong et al. (2006) recorded improved maize performance from foliar application of liquid manure in acid sands of Akwa Ibom State. Timbilla (1998) had earlier reported a significant increase in yield of cabbage from the use of Algifol nutrient solution combined with soil applied NPK fertilizers.

The expansion of tomato growing belts in the savanna of Nigeria as a result of increased demand and consumption of the crop by both human and tomato processing industries coupled with low soil productivity have therefore enforced the need for alternative approaches to secure a more nutrient balance towards a

B. O. Ukem, Dept. of Soil Sciences, Faculty of Agriculture/Institute for Agric. Research, Ahmandu Bello University, Zaria, Nigeria 
more efficient crop performance. In view of this, complementary application of inorganic NPK and foliar Algifol nutrient solution became optimal. Algifol is an organic based nutrient solution processed from brown algae as concentrates. It is usually applied foliarly to crops and contains mainly micronutrients, plant hormones and enzymes but deficient in the major elements like $\mathrm{N}$ and $\mathrm{P}$ except for potassium where its concentration is moderate (Fleming, 1996; Timbilla, 1998). Nutrient composition of Algifol solution is presented in Table 1. The study was therefore set up to evaluate the effect of single and complementary use of NPK and Algifol nutrient solution on growth and yield of tomato in a savanna soil of Nigeria.

Table 1: Chemical composition of Algifol nutrient solution

\begin{tabular}{ll}
\hline Chemical Components & Values \\
\hline Phosphorus (\%) & 0.09 \\
Potassium (\%) & 32.68 \\
Calcium (\%) & 6.00 \\
Sodium $(\%)$ & 6.47 \\
Zinc $\left(\mathrm{mgkg}^{-1}\right)$ & 3.75 \\
Iron $\left(\mathrm{mgkg}^{-1}\right)$ & 20.00 \\
Manganese $\left(\mathrm{mgkg}^{-1}\right)$ & 6.25 \\
Copper $\left(\mathrm{mgkg}^{-1}\right)$ & 2.50 \\
\hline
\end{tabular}

\section{MATERIALS AND METHOD}

The study was conducted in a greenhouse at Samaru (Latitude $11^{0} 11^{\prime} \mathrm{N}$ and Longitude $7^{0} 38^{\prime} \mathrm{E}$ ) in the Northern Guinea Savanna (NGS) agro-ecological zone of Nigeria. Soils of the NGS are generally coarse textured, acidic in reaction, low in total $N$, available $P$ and organic carbon content and have a prevalence of a low activity clay in their micelle (Lombin, 1987; Bationo et al., 1986). Cation Exchange Capacity (CEC) is also low thus accounting for the inability of the soil to retain cations and a consequent low fertility. The soil is classified as an Alfisol derived from the basement complex rocks with some recent aeolian deposits (Ojanuga, 1979).

Table 2: $\quad$ Physico-chemical characteristics of the soil (20cm soil depth)

\begin{tabular}{|c|c|}
\hline Soil Property & Values \\
\hline Sand $\left(\mathrm{gkg}^{-1}\right)$ & 371 \\
\hline Silt $\left(g k g^{-1}\right)$ & 400 \\
\hline Clay $\left(\mathrm{gkg}^{-1}\right)$ & 229 \\
\hline Textural Class & Loam \\
\hline $\mathrm{pH}\left(1: 2.5 \mathrm{w} / \mathrm{v} \mathrm{H}_{2} \mathrm{O}\right)$ & 5.0 \\
\hline $\mathrm{pH}\left(1: 2.5 \mathrm{w} / \mathrm{v}, 0.01 \mathrm{M} \mathrm{CaCl}_{2}\right)$ & 4.7 \\
\hline Organic Carbon $\left(\mathrm{gkg}^{-1}\right)$ & 5.4 \\
\hline Total N $\left(\mathrm{gkg}^{-1}\right)$ & 1.27 \\
\hline Bray - 1 Available P $\left(\mathrm{mgkg}^{-1}\right)$ & 2.69 \\
\hline Exchangeable $\mathrm{Ca}\left(\mathrm{cmolkg}^{-1}\right)$ & 3.6 \\
\hline Exchangeable $\mathrm{Mg}\left(\mathrm{cmolkg}^{-1}\right)$ & 0.39 \\
\hline Exchangeable $\mathrm{K}\left(\mathrm{cmolkg}^{-1}\right)$ & 0.47 \\
\hline Exchangeable $\mathrm{Na}\left(\mathrm{cmolkg}^{-1}\right)$ & 0.21 \\
\hline CEC $\left(\mathrm{cmolkg}^{-1}\right)$ & 4.67 \\
\hline Extractable Zn $\left(\mathrm{mgkg}^{-1}\right)$ & 6.8 \\
\hline Extractable Fe (mgkg $\left.{ }^{-1}\right)$ & 18.0 \\
\hline Extractable Cu $\left(\mathrm{mgkg}^{-1}\right)$ & 2.0 \\
\hline Extractable $\mathrm{Mn}\left(\mathrm{mgkg}^{-1}\right)$ & 18.0 \\
\hline
\end{tabular}

Composite soil samples were collected at a depth of 0 $20 \mathrm{~cm}$ at the Institute of Agricultural Research (IAR) Experimental Farms at Samaru. The soil samples were weighed $(10 \mathrm{~g})$ and scooped into a 15 litre plastic pots. Representative samples were taken, air-dried and sieved through a $2 \mathrm{~mm}$ mesh for soil physical and chemical analyses. The result of this analysis is presented in Table 2. The treatments were 2, 1, 12 and $2 \mathrm{Alg}$ at the rate of $(5,10,15,20 \mathrm{ml}$ Algifol per $100 \mathrm{ml}$ of water or $0.5 \mathrm{~L}, 1 \mathrm{~L}, 1.5 \mathrm{~L}$ and $2 \mathrm{~L}$ Algifol per hectare) from the prescribed application rate of one litre of the concentrated solution to 1000 litres of water to the hectare (Timbilla, 1998). Treatments from nutrient solution and solid NPK were incorporated by foliar an soil application respectively. Four sprays were applied at 20 days interval beginning from 2 weeks after transplanting (WAT). The NPK treatments were 3, 2, : and Full NPK representing 187, 375, 562 and $750 \mathrm{kgNha}^{-1} ; 75,150,225$ and $300 \mathrm{kgha}^{-1} \mathrm{P}_{2} \mathrm{O}_{5}$ and $\mathrm{K}_{2} \mathrm{O}$ respectively at the rate of $\left(125: 50: 50 \mathrm{Kgha}^{-1}, \mathrm{~N}, \mathrm{P}_{2} \mathrm{O}_{5}\right.$ and $\mathrm{K}_{2} \mathrm{O}$ ) being the optimum recommendation for tomato in the area (Adepetu et al., 1989). The combined treatments were $2 \mathrm{Alg}+$ Full NPK; $1 \mathrm{Alg}+$ $3 \mathrm{NPK} ; 1 \mathrm{Alg}+$ 2NPK; $1 \mathrm{Alg}+\mathrm{NPK} ; 1 \mathrm{Alg}+$ Full NPK; 
$12 \mathrm{Alg}+2 \mathrm{NPK}$ and $2 \mathrm{Alg}+3 \mathrm{NPK}$ at the same rate as that for Algifol and NPK.

Nitrogen was split-applied first at transplanting, where one third of the recommendations $(62,125,187$ and $250 \mathrm{kgNha}^{-1}$ ) was applied at each split application then at 3 and 6WAT while $P$ and $K$ were applied at transplanting. Four tomato seedlings (ROMA-VF variety) were sown per pot after being raised in the nursery for 4 weeks and at 2WAT, they were thinned down to 2 plants per pot by and maintained at field capacity by regular irrigation. All the treatments were completely randomized with three replications each having one control. Data were collected on plant height, number of leaves, number of flowers per plant, and at harvest (13WAT), fresh fruit yield per plant was determined. The fresh fruits were cut-open and then oven-dried for two weeks at $65^{\circ} \mathrm{C}$ and the dry weight determined. Analytical methods used for the characterization of Algifol nutrient solution and soil were:

Particle size analysis was determined using the Bouyoucos hydrometer method (Day, 1965). Soil pH was determined in water and $0.01 \mathrm{M} \mathrm{CaCl}{ }_{2}$ soil to solution ratio of 1:2.5 with a glass electrode $\mathrm{pH}$ meter. Total $\mathrm{N}$ was done by the micro Kjeldahl method (Bremner and Mulvaney, 1982); available P by Bray No.1 method (Bray and Kurtz, 1945); organic carbon content was determined by the method of Walkley and Black as modified by Nelson and Sommers (1982); and exchangeable bases by extraction with 1 neutral $\mathrm{NH}_{4} \mathrm{OAc}$ at a pH 7.0. The amounts of $\mathrm{K}$ and $\mathrm{Na}$ were determined on EEL flame photometer; $\mathrm{Ca}$ and $\mathrm{Mg}$ on Atomic Absorption Spectrophotometer. Cation exchange capacity was determined by displacement with $1 \mathrm{~N} \mathrm{NH}_{4} \mathrm{OAc}$ at a $\mathrm{pH} 7.0$.

\section{RESULTS AND DISCUSSION}

\section{Soil}

Physical and chemical analyses of the soil used indicated a loamy texture showing that the soil does not exhibit the dominant physical properties of any of the three primary soil particles. The soil is acidic in soil reaction which is capable of reducing retention of basic cations in the soil colloid. Increased consumption of inorganic nitrogenous fertilizers contributes to a high acidifying effect of the savanna soils, therefore amendments with organic based nutrients either as foliar sprays or soil applied is suggested. The content of $\mathrm{N}$ and $\mathrm{P}$ was so low $\left(1.27 \mathrm{~g} \mathrm{Kg}^{-1}\right.$ and $\left.2.69 \mathrm{mg} \mathrm{Kg}^{-1}\right)$ respectively, suggesting an acute decline of organic matter content in the savanna soil which is essentially needed to enhance soil fertility restoration and yield enough nutrients for sustainable plant growth. The results obtained are generally consistent with the ones previously recorded in Northern Guinea savanna zone of Nigeria (Ojanuga, 1979; Lombin, 1987; Onyinlola, 1997).

\section{Effect of Algifol nutrient solution and inorganic NPK fertilizers on plant height}

Plant height was not significantly affected at 6 and 12 weeks after transplanting (WAT) in 1999, however, there appeared a progressive trend in height increases from 6WAT to 12WAT (Table 3). Foliarly applied nutrient solution recorded more height than soil applied NPK even though their treatment means were not significantly different. Even though there was no significant difference in stalk height from the nutrient solution and NPK treatments (Table 3), the nutrient solution recorded taller plants over the soil applied NPK which is attributed to the rapid assimilation of nutrients by the plant to enhance vegetative growth relative to soil nutrient uptake where nutrient losses particularly nitrate anion leaching and phosphate fixation are prevalent.

Treatments effects on plant height in the second planting in 2000 was not significant at 6WAT but highly significant $(P=0.01)$ at 12WAT (Table 3$)$. The best performance at 12WAT was recorded from the Algifol and NPK combination of $1 / 2 \mathrm{Alg}+$ Full NPK though the result was not significantly different from $1 \mathrm{Alg}$ and $1 \mathrm{Alg}$ $+3 / 4$ NPK respectively (Table 3 ).

It is observed that at the initial growth phase, nutritional needs of the crop were satisfied by the applied nutrient rates but at the advancement of growth phase to the period of fruits emergence, there was a greater food demand by the crop hence the superiority of the nutrient combinations over the foliarly or soil applied rates of Algifol and NPK alone. Results obtained as means at 12 WAT in 2000 were $59.6 \mathrm{~cm}$, $52.6 \mathrm{~cm}$ and $41.5 \mathrm{~cm}$ respectively in favour of combined doses, foliar Algifol solution and NPK alone. Tarfa et al, (2001) reported a significant performance in maize production in the savanna of Nigeria with the complementary use of foliage of Azadirachta indica, Parkia biolobosa and NPK over the organic nutrients or NPK alone. In view of the low fertility conditions of the savannah soils induced by continuous cultivation, therefore, judicious use of organic and inorganic fertilizers is recommended. 
Table 3: Effet of Algifo nutrient solution and inorganic NPK fertilizer on plant height

\begin{tabular}{|c|c|c|c|c|}
\hline Trt rate & \multicolumn{4}{|c|}{ WAT (cm ) } \\
\hline & \multicolumn{2}{|c|}{1999} & \multicolumn{2}{|c|}{2000} \\
\hline & 6 & 12 & 6 & 12 \\
\hline Control & 10.43 & 27.08 & 10.80 & $33.20^{\text {et }}$ \\
\hline $1 / 2 \mathrm{Alg}$ & 8.63 & 35.33 & 15.93 & $51.40^{\mathrm{abcd}}$ \\
\hline $1 \mathrm{Alg}$ & 14.75 & 44.80 & 16.55 & $67.38^{a}$ \\
\hline $1 \frac{1}{2} \mathrm{Alg}$ & 12.00 & 31.05 & 16.55 & $42.68^{\text {cdet }}$ \\
\hline $2 \mathrm{Alg}$ & 14.13 & 39.63 & 16.13 & $50.13^{\mathrm{abcde}}$ \\
\hline $1 / 4$ NPK & 10.13 & 18.75 & 12.18 & $29.70^{\dagger}$ \\
\hline $1 / 2$ NPK & 11.63 & 35.00 & 16.30 & $46.68^{\text {bcdet }}$ \\
\hline $3 / 4$ NPK & 10.50 & 32.95 & 17.68 & $35.33^{\text {det }}$ \\
\hline Full NPK & 10.63 & 34.83 & 16.13 & $56.45^{\mathrm{abc}}$ \\
\hline $1 / 2$ Alg + Full NPK & 10.90 & 44.83 & 16.13 & $67.75^{a}$ \\
\hline $1 \mathrm{Alg}+1 / 4 \mathrm{NPK}$ & 12.75 & 47.25 & 16.63 & $63.58^{a b}$ \\
\hline $1 \mathrm{Alg}+1 / 2 \mathrm{NPK}$ & 12.33 & 42.20 & 15.08 & $61.58^{a b}$ \\
\hline $1 \mathrm{Alg}+3 / 4 \mathrm{NPK}$ & 8.00 & 43.50 & 15.98 & $67.08^{a}$ \\
\hline $1 \mathrm{Alg}+$ Full NPK & 9.23 & 29.33 & 13.63 & $62.38^{a b}$ \\
\hline $11 / 2$ Alg + $1 / 2$ NPK & 12.13 & 45.63 & 15.80 & $61.58^{a b}$ \\
\hline $2 \mathrm{Alg}+1 / 4 \mathrm{NPK}$ & 8.13 & 28.13 & 15.18 & $36.65^{\mathrm{det}}$ \\
\hline F ratio & NS & NS & NS & $* *$ \\
\hline SE \pm & 2.12 & 6.29 & 1.32 & 5.17 \\
\hline
\end{tabular}

Means carrying the same letter(s) are not significantly different $(\mathrm{P}=0.05)$ according to Duncan's multiple range test. NS $=$ Not significant ${ }^{*}=$ Significant at $1 \%$

Table 4 Effect of Algifol nutrient solution and inorganic NPK fertilizer on number of leaves

\begin{tabular}{|c|c|c|c|c|c|}
\hline Trt rate & WAT & & & & \\
\hline & 1999 & & 2000 & & \\
\hline & 6 & 12 & 6 & 12 & \\
\hline Control & 44.00 & $159.00^{\mathrm{bcde}}$ & 38.00 & 134.50 & det \\
\hline 2 Alg & 44.00 & $209.00^{\text {bcde }}$ & 57.00 & 221.50 & bcdet \\
\hline 1Alg & 71.50 & $282.50^{\mathrm{ab}}$ & 70.00 & 289.50 & $\mathrm{ab}$ \\
\hline 12Alg & 48.50 & $147.00^{\text {bcde }}$ & 62.50 & 151.50 & cdef \\
\hline 2Alg & 67.00 & $159.00^{\mathrm{bcde}}$ & 63.00 & 161.50 & bcdet \\
\hline $3 N P K$ & 40.50 & $81.50^{\mathrm{e}}$ & 52.50 & 94.50 & $\dagger$ \\
\hline 2NPk & 50.50 & $102.50^{\mathrm{de}}$ & 61.50 & 107.50 & $\dagger$ \\
\hline : NPK & 49.00 & $108.00^{\text {cde }}$ & 60.50 & 122.50 & ef \\
\hline Full NPK & 46.00 & $216.50^{\text {bcde }}$ & 54.50 & 217.50 & bcdef \\
\hline 2Alg + Full NPK & 51.00 & $300.00^{\mathrm{ab}}$ & 57.50 & 295.00 & $\mathrm{ab}$ \\
\hline $1 \mathrm{Alg}+3 \mathrm{NPk}$ & 62.50 & $257.00^{\mathrm{bcd}}$ & 75.00 & 254.00 & abcde \\
\hline $1 \mathrm{Alg}+2 \mathrm{NPK}$ & 72.00 & $277.50^{\mathrm{ab}}$ & 65.50 & 277.00 & $\mathrm{abc}$ \\
\hline $1 \mathrm{Alg}+: \mathrm{NPK}$ & 48.00 & $266.50^{\mathrm{bc}}$ & 56.50 & 262.50 & abcd \\
\hline 1Alg + Full NPK & 45.50 & $203.00^{\text {bcde }}$ & 60.00 & 199.00 & bcdef \\
\hline $12 \mathrm{Alg}+2 \mathrm{NPK}$ & 52.50 & $422.00^{\mathrm{a}}$ & 71.50 & 368.50 & a \\
\hline $2 \mathrm{Alg}+3 \mathrm{NPK}$ & 50.00 & $155.00^{\text {bcde }}$ & 56.00 & 193.00 & bcdet \\
\hline F ratio & NS & ** & NS & $* *$ & \\
\hline SE $\forall$ & 10.85 & 46.24 & 8.75 & 39.45 & \\
\hline
\end{tabular}

Means carrying the same letter(s) are not significantly different $(\mathrm{P}=0.05)$ according to Duncan=s multiple range test. NS $=$ Not significant $\quad *=$ Significant at $5 \% \quad{ }^{* *}=$ Significant at $1 \%$ 
Effect of Algifol nutrient solution and inorganic NPK fertilizers on number of leaves

Foliage production in the first cropping in 1999 was not significant at 6WAT but highly significant at 12WAT. A similar effect was recorded in 2000 (Table 4). In both years, the combined application of soil and foliar proved widely superior to either soil or foliar application. This further demonstrates the positive impact of combined use of organic and inorganic nutrient sources over their separate application as this greatly enhances efficiency and providing more nutrients to the growing crops especially in locations where adverse cultural practices seriously diminish soil nutrient credit.

The effect of soil applied NPK on number of leaves per plant in the two years were consistently and significantly lower than that obtained from either the foliarly applied nutrient solution or combined treatments of nutrient solution and NPK. Results presented as means at 12WAT are 127, 199 and 269 in 1999; 136, 206 and 264 in 2000 respectively for NPK rates, nutrient solution and the combined nutrient solution and NPK. This suggests an insufficient nutrient balance in the NPK rates to satisfy crop requirements. When the soil fertility condition is initially low, application of the recommended rates of fertilizers and adequate management become necessary if crop production is to be sustained.

\section{Effect of Algifol nutrient solution and inorganic NPK fertilizers on flowering}

The effect of the fertilizer treatments on flowering at the first cropping in 1999 was highly significant $(P=0.01)$ being an indication of a positive effect of the treatments on tomato flowering. Of all the treatments, the highest number of flowers was obtained from $12 \mathrm{Alg}+2 \mathrm{NPK}\left(1.5 \mathrm{~L} \mathrm{Alg} \mathrm{ha}{ }^{-1}+375 \mathrm{~kg} \mathrm{~N}+150 \mathrm{~kg}\right.$ $\mathrm{P}_{2} \mathrm{O}_{5}+150 \mathrm{~kg} \mathrm{~K}_{2} \mathrm{O}$ ha $^{-1}$ ), though this was not significantly different from 2 rate NPK, $1 \mathrm{Alg}+2 \mathrm{NPK}$ and 1 rate Alg $\left(375 \mathrm{~kg} \mathrm{~N}+150 \mathrm{~kg} \mathrm{P}_{2} \mathrm{O}_{5}+150 \mathrm{~kg} \mathrm{~K}_{2} \mathrm{O} \mathrm{ha}^{-1}\right.$ and $1 \mathrm{~L} \mathrm{Alg} \mathrm{ha}^{-}$ $+375 \mathrm{~kg} \mathrm{~N}+150 \mathrm{~kg} \mathrm{P}_{2} \mathrm{O}_{5}+150 \mathrm{~kg} \mathrm{~K}_{2} \mathrm{O} \mathrm{ha}^{-1}$ and $1 \mathrm{~L} \mathrm{Alg}$ $\mathrm{ha}^{-1}$ ) (Table 5). The result obtained from control indicated that the soil was initially low in plant nutrients, however its treatment mean was not significantly different from the values from 12 rate Alg, 2 rate Alg, 3 rate NPK and : rate NPK (Table 5). There is an indication that these treatments were nutritionally inadequate especially for a high nutrient requiring crop like tomato in the northern guinea savanna zone of Nigeria.

During the second trial in 2000, the treatment effect on flowering was also highly significant $(P=0.01)$. The results revealed that reduced Algifol levels (2Alg and $1 \mathrm{Alg}$ ) seemed to be more effective in tomato flowering than the relatively higher levels such as 12Alg, $2 \mathrm{Alg}$ and as well as the higher Algifol levels combining with reduced NPK levels like $2 \mathrm{Alg}+3 \mathrm{NPK}$. The higher levels of Algifol may have been to+o concentrated and thereby resulting in flower abortion with a consequent reduction in flowering. Abubakar (1999) recorded a similar result from the use of Urea solution on maize where the higher Urea solution scorched the foliage and thereby initating senescence of the plant. In the two years of study, combined treatments were most effective as they produced the most luxuriant and highest number of flowers followed by single Algifol while inorganic NPK doses ranked last, thus emphasising the serious fertility problem of soils of the area.

Table 5: Effect of Algifol nutrient solution and inorganic NPK fertilizer on flowering and fruit yield

\begin{tabular}{|c|c|c|c|c|c|c|c|c|}
\hline \multirow[t]{3}{*}{ Trt rate } & \multirow{2}{*}{\multicolumn{4}{|c|}{1999}} & \multirow{2}{*}{\multicolumn{4}{|c|}{2000}} \\
\hline & & & & & & & & \\
\hline & $\begin{array}{l}\text { No. } \\
\text { flowers/ } \\
\text { plant }\end{array}$ & $\begin{array}{l}\text { of } \begin{array}{lr}\text { Fresh } & \text { fruit } \\
\text { yield/ } \\
(\mathrm{g})\end{array} \\
\begin{array}{l}\text { plant } \\
\end{array}\end{array}$ & $\begin{array}{l}\text { Dry } \\
\text { yield/ } \\
\text { (g) }\end{array}$ & $\begin{array}{l}\text { No. } \\
\text { flowers/ } p\end{array}$ & $\begin{array}{r}\text { of } \\
\text { Dlant }\end{array}$ & $\begin{array}{lr}\text { Fresh } & \text { fruit } \\
\text { yield/ } & \text { plant } \\
(\mathrm{g}) & \end{array}$ & $\begin{array}{l}\text { Dry } \\
\text { yield/ } \\
\text { (g) }\end{array}$ & $\begin{array}{r}\text { fruit } \\
\text { plant }\end{array}$ \\
\hline Control & $16.50^{d}$ & $118.50^{\text {bcde }}$ & $8.50^{\mathrm{e}}$ & 12.50 & e & $102.50^{\mathrm{de}}$ & 7.50 & e \\
\hline 2 Alg & $98.00^{\mathrm{abc}}$ & $501.00^{\mathrm{ab}}$ & $47.50^{\mathrm{abcd}}$ & 126.00 & c & $525.00^{\mathrm{abc}}$ & 49.50 & $\mathrm{~cd}$ \\
\hline $1 \mathrm{Alg}$ & $105.50^{\mathrm{a}}$ & $197.00^{\text {abcde }}$ & $24.50^{\text {cde }}$ & 166.50 & a & $382.50^{\mathrm{bc}}$ & 47.50 & $\mathrm{~cd}$ \\
\hline 12Alg & $22.50^{\mathrm{d}}$ & $40.00^{\mathrm{de}}$ & $5.50^{\mathrm{e}}$ & 81.00 & d & $330.00^{\mathrm{cd}}$ & 52.50 & bcd \\
\hline $2 \mathrm{Alg}$ & $22.50^{\mathrm{d}}$ & $78.50^{\text {cde }}$ & $7.50^{\mathrm{e}}$ & 15.50 & e & $97.00^{\text {de }}$ & 8.75 & e \\
\hline 3NPK & $12.00^{d}$ & $15.50^{\mathrm{e}}$ & $2.00^{\mathrm{e}}$ & 10.50 & e & $37.00^{\mathrm{e}}$ & 6.00 & e \\
\hline $2 \mathrm{NPk}$ & $115.00^{\mathrm{a}}$ & $574.00^{\mathrm{a}}$ & $65.50^{a}$ & 139.00 & $\mathrm{bc}$ & $677.50^{\mathrm{a}}$ & 76.00 & $\mathrm{ab}$ \\
\hline :NPK & $20.00^{d}$ & $73.00^{\text {cde }}$ & $7.00^{\mathrm{e}}$ & 17.00 & e & $78.00^{\mathrm{de}}$ & 8.00 & e \\
\hline Full NPK & $53.00^{\mathrm{bdc}}$ & $129.50^{\text {bcde }}$ & $15.50^{\text {de }}$ & 96.00 & d & $308.50^{\text {cde }}$ & 40.00 & d \\
\hline 2Alg + Full NPK & $102.00^{\mathrm{ab}}$ & $484.50^{\mathrm{abc}}$ & $69.00^{\mathrm{a}}$ & 127.00 & c & $665.00^{a}$ & 77.50 & $a b$ \\
\hline $1 \mathrm{Alg}+3 \mathrm{NPk}$ & $101.50^{\mathrm{ab}}$ & $482.50^{\mathrm{abc}}$ & $57.50^{\mathrm{ab}}$ & 98.50 & d & $645.00^{a b}$ & 79.00 & a \\
\hline $1 \mathrm{Alg}+2 \mathrm{NPK}$ & $112.50^{a}$ & $450.00^{\mathrm{abcd}}$ & $49.50^{\mathrm{abc}}$ & 156.50 & $a b$ & $702.50^{a}$ & 70.00 & $\mathrm{abc}$ \\
\hline $1 \mathrm{Alg}+\mathrm{:NPK}$ & $82.00^{\mathrm{abc}}$ & $164.00^{\text {abcde }}$ & $26.00^{\text {bcde }}$ & 99.50 & d & $757.50^{\mathrm{a}}$ & 83.50 & a \\
\hline 1Alg + Full NPK & $48.00^{\mathrm{cd}}$ & $198.00^{\text {abcde }}$ & $22.50^{\text {cde }}$ & 99.00 & d & $492.50^{\mathrm{abc}}$ & 40.00 & d \\
\hline $12 \mathrm{Alg}+2 \mathrm{NPK}$ & $118.50^{a}$ & $264.50^{\text {abcde }}$ & $42.00^{\mathrm{abcd}}$ & 159.00 & $a b$ & $522.50^{\mathrm{abc}}$ & 72.50 & $a b c$ \\
\hline $2 \mathrm{Alg}+3 \mathrm{NPK}$ & $13.00^{d}$ & $69.00^{\text {cde }}$ & $5.50^{\mathrm{e}}$ & 11.00 & $\mathrm{e}$ & $48.50^{\mathrm{e}}$ & 4.40 & e \\
\hline $\mathrm{F}$ ratio & ** & * & $* *$ & $* *$ & & ** & $* *$ & \\
\hline SE $\forall$ & 15.56 & 122.22 & 9.85 & 6.98 & & 83.31 & 7.73 & \\
\hline
\end{tabular}

Means carrying the same letter(s) are not significantly different $(P=0.05)$ according to Duncan=s multiple range test. NS $=$ Not significant $\quad *=$ Significant at $5 \% \quad * *=$ Significant at $1 \%$ 
Effect of Algifol nutrient solution and inorganic NPK fertilizer on fresh fruit yield

The effect of the treatments on fresh fruits yield during the first cropping in 1999 was highly significant $(P=0.01)$, indicating a positive response of the crop to the fertilizer rates. Among the Algifol nutrient solution rates, $2 \mathrm{Alg}\left(0.5 \mathrm{~L} \mathrm{Alg} \mathrm{ha}{ }^{-1}\right)$ made a much more positive impact than the higher Algifol level of $2 \mathrm{Alg}$ or $2 \mathrm{~L} \mathrm{Alg} \mathrm{ha}{ }^{-1}$ $(20 \mathrm{ml}$ of Algifol concentrate in $100 \mathrm{ml}$ of water), which may be as a result of the scorching effect of leaves by the higher concentrated nutrient solution and a consequent yield reductions. A similar effect was earlier reported by Obakin (1982) and Abubakar (1999). There was no consistent performance recorded from the applied NPK rates, but it appeared that the higher NPK levels were more effective than the reduced levels (Table 5). This may be attributed to the inherently low fertility condition of the soil which has been widely reported among the savanna agro-ecological zones of Nigeria (Lombin, 1987 and Chude et al., 2001). During the second trial in 2000, response of tomato to the fertilizer treatments on fresh fruit yield was highly significant $(P=0.01)$, with the best yield recorded from a combined application of $1 \mathrm{Alg}+3 / 4 \mathrm{NPK}\left(1 \mathrm{~L} \mathrm{Alg} \mathrm{ha}{ }^{-1}+\right.$ $562 \mathrm{~kg} \mathrm{~N}+225 \mathrm{~kg} \mathrm{P}_{2} \mathrm{O}_{5}+225 \mathrm{~kg} \mathrm{~K}_{2} \mathrm{O} \mathrm{ha}^{-1}$ ) though not significantly different from $1 \mathrm{Alg}+2 \mathrm{NPK}, 2 \mathrm{Alg}+$ Full NPK and 2NPK (Table 5).

The mean fruit yields obtained in 1999 from the pot treated with Algifol nutrient solution, soil applied NPK and a combination of the two were $204 \mathrm{~g} ; 198 \mathrm{~g}$ and $302 \mathrm{~g}$ representing $30 \%, 28 \%$ and $43 \%$ of fruit yield respectively. Similarly, the results in 2000 were $334 \mathrm{~g}$; $275 \mathrm{~g}$ and $547 \mathrm{~g}$ or $29 \%, 24 \%$ and $47 \%$ of fruit yield respectively. The overwhelming effect of the combined treatments in enhancing tomato yield over the foliar solution or NPK alone is indicative of the inadequate nutrient resources in the un-combined fertilizer doses to enable the plant attain its full growth and yield potentials. Therefore, soil fertility management that provides adequate nutrients for plant use should be continuously exploited in the savanna for the overall benefit of crop production.

\section{Effect of Algifol nutrient solution and inorganic NPK fertilizer on dry fruit yield}

The fertilizer treatments effect on dry fruit yield at the first cropping in 1999 was highly significant $(P=0.01)$. The best yield was obtained from the combined treatment of $2 \mathrm{Alg}+$ Full NPK $\left(0.5 \mathrm{~L} \mathrm{Alg} \mathrm{ha}^{-1}+\right.$ $750 \mathrm{~kg} \mathrm{~N}+300 \mathrm{~kg} \mathrm{P}_{2} \mathrm{O}_{5}+300 \mathrm{~kg} \mathrm{~K}_{2} \mathrm{O}$ ha ${ }^{-1}$ ) though its effect was not significantly different from 2 rate NPK. Also, 3 rate NPK recorded the least yield though its performance was not significantly different from control, 12 rate Alg, 2 rate Alg, : rate NPK and 2 Alg + 3NPK (Table 5).

During the second trial in 2000 , the treatment effect on dry fruit yield was also highly significant $(P=0.01)$. As was the trend in the previous trial, combined Algifol and NPK treatments gave the highest yields compared to either the single Algifol or NPK rates. This performance was similarly obtained by Timbilla (1998) in a cabbage cultivation in Kumasi, Ghana, where Algifol and NPK combinations recorded the best yield than the single application of Algifol doses.
Combined Algifol and NPK rates seemed to be nutritionally more effective compared to their single doses. Obakin (1982) also obtained a significant yield increase from the complementary application of Agromax foliar and inorganic NPK fertilizers on a sugarcane cultivation at Bida area of Niger State of Nigeria.

\section{Correlation Studies}

There was a positive and a highly significant correlation $\left(r=0.75^{\star *} ; 0.86^{\star \star}\right)$ between number of flowers per plant and fresh fruits yield and between number of flowers and dry fruits yield respectively. The positive and significant correlation between number of flowers produced per plant and fruit yield sows that flower abortion was minimal during the reproductive growth stage and fertilizer treatments significantly influenced and significantly influenced the growth and yield of the crop. Treatments which produced more flowers per plant equally recorded more fruit yields.

\section{CONCLUSION}

The superiority of the combined application of Algifol nutrient solution and NPK treatments over the nutrient solution or NPK alone on the growth and yield of tomato is indicative of the positive and significant impact of this combination on tomato cultivation in the savanna of Nigeria. It is therefore expedient that such combinations be further tested and adopted for improved crop yields.

\section{ACKNOWLEDGEMENT}

The author acknowledges the invaluable contributions of Professor V. O. Chude, Professor B. A. Raji, Dr. I. Y. Amapu and Mr. Joseph Osaka of the Institute of Agricultural Research, Ahmadu Bello University, Zaria, Nigeria, for materials and logistics needed for the research.

\section{REFERENCES}

Abubakar, M., 1999. Response of maize (Zea mays L.) to soil and foliar applied Urea in Northern Guinea Savanna of Nig. M.Sc. Thesis. Ahmadu Bello University, Zaria, 84pp.

Adepetu, J. A.., Enwenzor; W. O., Udo, E. J., Usoro, N. J., Ayotade, K. A., Chude, V. O. and Udegbe, C. I., 1989. Fertilizer Use and Management Practices in Nigeria (Series No. 2). Fertilizer Procurement and Distribution Division of the Fed. Min. of Agriculture, pp.163.

Bationo, A., Mughogho, S. K. and Mokwunye, A. U., 1986. Agronomic evaluation of phosphate fertilizers in tropical Africa. In Mokwunye, A. U. and Vlek, P.L.G. (Eds) Management of Nitrogen and Phosphorus fertilizers in sub-Saharan Africa, pp.283-318. 
Bray, R. H. and Kurtz, L. T., 1945. Determination of total, organic and available forms of phosphorus in soils. Soil Science Journal 59:39-45.

Bremner, J. M., 1982. Total Nitrogen, pp.699-709. In: Page, A. L., Miller, R. H. and Keeney, D. R. (1982) (eds.) Methods of Soil Analysis Part 2. 2nd ed. Agron. Monogr. 9. ASA and SSSA, Madison, Wis.

Chude, V. O., Amapu, I. Y., Yusuf, A. A., Singh, U., Breman, H. and Dejean, P., 2001. Validation of CERES - maize model under sub-humid tropical conditions. Nig. J. Soil Res. 2:37-42.

Cooke, C. W., 1982. Fertilizing for maximum yield. Collins Professional and Technical Books, 3rd Ed., p.465.

Day, P. R., 1965. Particles fractionation and particle size analysis. In: C. A. Black (ed.). Methods of soil analysis part 1. Agron. No. 9. ASA Madison, Wisconsin, USA. Pp.545-577.

Effiong, G. S., Ogburia, M. N., Ndaeyo, N. U. and Uduk, E. M., 2006. Response of folair application of liquid manure in acid sands of Akwa lbom State, Southern Nigeria. Journal of Sustainable Tropical Agric, Res. Vo. 17:60-65.

Federal Office of Statistics., 2004. The Nigerian Statistical Fact Sheets on Economic and Social Development, National Bureau of Statistics, June, 2005, pp.12-13.

FOA ., $1989 . \quad$ Sustainable agricultural production.Implication for International Agricultural Research. Technical Advisory Committee, CGIAR. FAO Research and Technical Paper No. 4, Rome,. Italy.

Fleming, C., 1996. Control of Nematode with Seaweed extracts. Applied Plant Science. Dept. Of Agric. For N. Ireland and the Queen's Univ. Of Belfast. In: Algifol Liquid Fertilizer Manual.

Hulugalle, N. R., Lal, R. and Opara-Nadi, O. A., 1987. Management of crop residue for cassava (Manihot esculenta) production on an acid ultisol in South Eastern Nigeria. Field Crops Research, 16:1-8.

Jones, M. J. and Wild, A., 1975. Soils of West African Savannah. Tech. Comm. No. 55. Commonwealth Bureau of Soils, Harpenden, England, 246pp.
Lombin, L. G., 1987. Fertilizer requirements of the major cereal crops in the Nigerian Savannah. Proceedings of the National Fertilizer Seminar held at Port Harcourt, (Oct., 28-30, 1987) pp.106-110.

Nelson, D. W. and Sommers, L. E., 1982. Total carbon, organic carbon and organic matter. p.570-571. In: Page, A. L., Miller, R. H. and Keeney, D. R. (1982) (eds.) Methods of soil analysis. Part 2, 2nd ed. Agron. Monogr. 9. ASA and SSSA, Madison, WI.

Nnadi, L. A. and Balasubramanian, V., 1980. Crop residue management and soil productivity in savanna area of Nigeria. In: Organic Recycling in Africa, FAO Soil Bulletin 43:106-120.

Obakin, F. O., 1982. Comparative study of the effects of AGROMAX liquid fertilizer and the solid conventional fertilizers on the growth, yield and quality of sugarcane. Paper presented at the 14th Annual Conference of Soil Sci. Soc. of Nig

Ojanuga, A. G., 1979. Clay mineralogy of soils in the Nigerian tropical savanna regions. Soil Sci. Soc. Am. J. 43: 1237-1242.

Onyinlola, E. Y., 1997. Boron requirement of tomato in some selected soils of the Nigerian savanna. An unpublished Ph.D thesis. Dept. of Soil Sci. Ahmadu Bello Univ., Zaria, pp.271.

Singh, Y., Singh, B., Maskina, M. S. and Meelu, O. P., 1995. Response of wetland rice to nitrogen from cattle manure and urea in a rice-wheat rotation. Tropical Agric. (Trinidad) Vol. 72, No. 2.

Tarfa, B. E., Uyovbisere, E. O., Chude, V. O., Raji, B. A. and Yaro, D. T., 2001. Effect of the complementary use of foliage of Azadirachta indica, Parkia biglobosa and NPK on yield and nutrients uptake of maize in a savanna soil. Nig. J. Soil Res. (2001) 2:43-50.

Timbilla, J. A., 1998. Performance of Algifol among other plant growth hormones and pesticides in cabbage cultivation. Bicontrol Unit, Plant Health Div. Crop. Res. Inst. Kumasi, Ghana. In Algifol Liq. Fert. Manual, 1999.

Uyovbisere, E. O. and Lombin, L. G., 1991. Efficient fertilizer use for increased crop production: the sub-humid Nigeria experience. Fertilizer Research 29:81-94 